DOI: 10.33766/2524-0323.91.286-294

УДК 343.983:343.53

Т. В. Романенко,

ад'юнкт кафедри криміналістики та судової медицини

Національної академії внутрішніх справ

(м. Київ, Україна)

e-mail:post@naiau.kiev.ua

iDhttps://orcid.org/0000-0001-9840-5230

\title{
СТАН НАУКОВИХ ДОСЛІДЖЕНЬ ПРОБЛЕМ РОЗСЛДУВАННЯ ШАХРАЙСТВ, УЧИНЕНИХ ІЗ ВИКОРИСТАННЯМ ЕЛЕКТРОННО-ОБЧИСЛЮВАЛЬНОЇ ТЕХНІКИ
}

У статті висвітлено стан наукових досліджень проблем розслідування шахрайств, учинених із використанням електронно-обчислювальної техніки. Установлено, що розвиток сучасних інформаційних технологій, удосконалення виробництва й розширення сфери застосування новітньої кібернетичної техніки дали можливість зародження специфічного, складного виду злочинних діянь, де комп'ютерне оснащення та електронна інформація є об'єктом протиправного посягання. Визначено, що поряд із позитивними здобутками, інформатизація супроводжується побічним негативним явищем криміногенного характеру, до якого належать злочини у сфері електронно-обчислювальних машин (комп' ютерів), систем і комп' ютерних мереж або ж «комп' ютерна злочинність» (скорочена назва цього виду злочинів). Констатовано відсутність єдиної думки щодо того, які саме елементи слід залучати до криміналістичної характеристики злочинів у сфері використання електронно-обчислювальної техніки (комп'ютерів), систем і комп'ютерних мереж і мереж електрозв' язку.

Ключові слова: електронна обчислювальна техніка, кібербезпека, комп'ютерні технології, розслідування шахрайства, шахрайство.

Постановка проблеми. В епоху стрімкого інформаційно-технологічного розвитку для всіх галузей суспільного функціонування стає характерним поступовий перехід на новий рівень прогресу, узвичаєним є використання технічного забезпечення - комп'ютерного обладнання та інтернет-ресурсів. Порівняння показника інформаційно-технологічного розвитку ще десятиліття тому й того, що є на сьогодні, дає змогу підсумувати: комп'ютерні технології розвиваються; інформаційний напрям упевнено займає активну позицію в усіх суспільних галузях (використання кредитної картки для збереження фінансів, оплачування послуг комунального обслуговування через мережу «Інтернет», передавання важливих даних за допомогою соціальних мереж, застосування електронних цифрових підписів тощо).

Завдяки стрімкому розвитку науково-технічного прогресу, інформатизації та комп'ютеризащії всіх сфер життєдіяльності суспільства, отримання, обробка, зберігання та передача інформації є життєво необхідним для економіки держави, військово-промислового комплексу, стратегічних питань геополітики, екології, торгівлі, культури тощо. Саме тому протиправне використання електронно-обчислювальної техніки (далі - ЕОТ), інформації, що циркулює в ній, і мереж передачі такої інформації й становить неабияку суспільну небезпеку [1].

(C) Романенко Т. В., 2020 
Розвиток сучасних інформаційних технологій, удосконалення виробництва й розширення сфери застосування новітньої кібернетичної техніки дали можливість зародження специфічного, складного виду злочинних діянь, де комп'ютерне оснащення та електронна інформація є об'єктом протиправного посягання [2, с. 12]. Водночас із позитивними здобутками інформатизація супроводжується побічним негативним явищем криміногенного характеру, до якого належать злочини у сфері електронно-обчислювальних машин (комп'ютерів), систем і комп'ютерних мереж або ж «комп'ютерна злочинність» (скорочена назва цього виду злочинів). На сучасному етапі технологізації суспільства відбувається перехід від простої поодинокої комп'ютерної злочинності до організованої - складної. Прослідковується динаміка ії злиття з міжнародним криміналітетом, що несе відповідну загрозу суспільству загалом [3]. Зазначимо, що така транскордонність утруднює для працівників правоохоронних органів різних держав можливість розкриття та розслідування цієї категорії злочинів.

Аналіз останніх досліджень і публікацій. У білышості документів, прийнятих на міжнародному рівні, зазначено, що для ефективної боротьби з такою злочинністю потрібне значно ширше, оперативне й налагоджене міжнародне співробітництво. Зокрема, у червні 2001 р. Свропейський комітет спільно з Комітетом експертів у дослідженні проблем злочинності розробили проєкт Конвенщії про кіберзлочинність. У листопаді того ж року Конвенщія була затверджена Комітетом міністрів Ради Свропи й підписана 35 державами, які взяли на себе зобов' язання боротьби зі злочинністю у цій сфері [4]. Тому проблема розслідування шахрайств, учинених з використанням ЕОТ, постійно перебувала в полі зору сучасних науковців, зокрема, Т. Аверьянова, Д. Азарова, Б. Андрєєва, Ю. Батуріна, О. Баранова, М. Вертузаєва, Т. Варфоломеєва, О. Волєводз, В. Гончаренка, В. Голубєва, М. Гуцалюка, В. Гавловського, В. Губанова, М. Карчевського, В. Колесник, О. Котляревського, В. Крилова, Р. Калюжного, М. Камлика, В. Міщенка, В. Оборського, Б. Романюка, О. Стрільціва, О. Усова, В. Хорста, В. Цимбалюка та інших.

Розробка проблем криміналістичної методики на цьому етапі стосувалася передусім окремих питань розслідування злочинів відповідно до побудови норм законодавства про кримінальну відповідальність [5; 6]. Зокрема, на думку Л. Кривоченка, конструкція «шахрайство, учинене шляхом незаконних операцій з використанням електронно-обчислювальної техніки», свідчить про специфічний спосіб учинення цього злочину, до того ж його небезпечність полягає в тому, що ця техніка значно полегшує вчинення шахрайства, дає змогу заволодівати значними коштами, завдаючи непоправної шкоди власникам [7, с. 160], а науковець М. Хавронюк вважає, що електронно-обчислювальна техніка в ч. 3 ст. 190 Кримінального кодексу України є засобом учинення шахрайства [8, с. 196].

Згодом, з огляду на накопичення емпіричного матеріалу та розвиток загальної теорії криміналістики, розпочалося вивчення методологічних засад цієї діяльності, іiі загальних положень, які нині складають базу кожної окремої методики [9; 10].

Різним аспектам комп' ютерної злочинності, способам і механізму їх учинення, технології та техніці виявлення та закріплення слідів, тактищі проведення слідчих дій приділяють увагу вітчизняні й зарубіжні вчені. Скажімо, дослідженнями окре- 
мих аспектів боротьби зі злочинами, що вчиняються з використанням комп'ютерних мереж загалом, і шахрайством зокрема, займаються такі вчені, як В. Бутузов, В. Гавловський, Д. Зиков, А. Комаров, В. Ларичев, А. Лебедєв, О. Лисодєд, О. Смаглюк, К. Тітуніна, С. Чернявський, В. Шеломенцев, О. Юрченко та інші.

Формулювання цілей. 3 огляду на викладене, метою статті обрано з' ясування стану наукових досліджень проблем розслідування шахрайств, учинених із використанням електронно-обчислювальної техніки (далі - ЕОТ).

Виклад основного матеріалу. Поняття «комп'ютерне шахрайство» 3'явилося ще в 70-ті рр. минулого століття, коли в розвинених країнах зріс рівень економічних злочинів [3], що зумовило потребу реформування законодавства. Але позищія законодавчих органів була спочатку дещо розмитою, адже, на перший погляд, могло б здатися, що треба тільки об'єднати низку кваліфікуючих ознак та чинних норм законодавства, проте під час ретельнішого вивчення конструкції таких злочинів стало очевидно, що тут можна твердити про появу нового способу й нового предмету посягань, що спричинило потребу введення нових складів у Кримінальний кодекс України, котрі містять відповідальність за такі види злочинів.

Це своєю чергою викликало плюралізм наукових позищійщодо трактування дефініцій понять «електронно-обчислювальна техніка», «комп'ютер», «кіберзлочинність» та ін. Для напрацювання дефініцій означених понять насамперед треба визначитися з терміном «кіберзлочинність». Як підсумовує А. Білоусов [11, с. 7], «кіберзлочинність» незрідка ототожнюють із терміном «комп'ютерна злочинність» [11, с. 12].

Криміналістична характеристика злочинів є предметом вивчення багатьох учених, серед яких: І. Возгрин, Л. Васильєв, Л. Самигін, В. Танасевич та інші. Проте на сьогодні серед науковців немає усталеної думки, які саме елементи треба включати до криміналістичної характеристики злочинів у сфері використання ЕОТ (комп' ютерів), систем і комп' ютерних мереж і мереж електрозв' язку.

Нині шахрайство $з$ використанням можливостей мережі «Ннтернет» зберігає сталу тенденщію до еволюціонування, з' являються нові його види чи вдосконалюються вже відомі, зокрема: у сфері дистанщійного банківського обслуговування, 3 електронними платіжними системами й системами експрес-оплати товарів і послуг (жебрацтво, фейкові банки, біржі пращі, електронні віртуальні гаманщі, фейкові листи від чужого імені, інтернет-аукціони, інтернет-лотереї, віртуальні казино й тоталізатори), кредитне шахрайство, кіберсквоттинг, рерайтинг, серфінг, креммінг, банкоматне шахрайство (фішинг, скіммінг, використання «білого пластику»), застосування штигунських програм (spyware, keyloggers), використання ноах-програмного забезпечення, sms-шахрайство тощо [12, с. 145].

3 огляду на це науковці активно розробляють питання, пов'язані з методикою розслідування шахрайств, учинених із використанням ЕОТ. Під криміналістичною методикою розкриття та розслідування комп'ютерних злочинів В. Голубєв розуміє сукупність наукових положень і рекомендацій, розроблених на їх основі, тобто науково обгрунтованих і апробованих на практищі порад щодо розкриття та розслідування таких злочинів [13, с. 65].

Учений О. Мотлях і собі, досліджуючи основні питання методики розслідування злочинів у сфері інформаційних комп' ютерних технологій, детально проаналізував криміналістичну характеристику злочинів цієї категорії як інформаційну 
модель, що являє собою систематизований опис типових криміналістично значущих ознак, які мають суттєве значення для виявлення та розслідування протиправних дій осіб у сфері комп' ютерних технологій. Серед основних структурних елементів криміналістичної характеристики автор пропонує розглянути такі:

- способи скоєння злочинів цієї категорії (способи безпосереднього доступу до комп' ютерної інформації або операційної системи; способи видаленого (опосередкованого) доступу; способи виготовлення, розповсюдження на технічних носіях шкідливих програм для ЕОТ);

- слідова картина цих злочинів (слідова картина незаконного втручання в роботу електронно-обчислювальних машин (комп' ютерів), систем і комп'ютерних мереж; слідова картина викрадення, привласнення, вимагання комп'ютерної інформації або заволодіння нею способом шахрайства чи зловживання службовим становищем; слідова картина порушення правил експлуатації автоматизованих електронно-обчислювальних систем);

- особа злочинця, мотиви й мета скоєння злочину (за статистичними даними вітчизняної та зарубіжної практик, вік осіб, які вчиняють комп'ютерні злочини, сягає від 15 до 45 років. Матеріали експертних досліджень визначають, що на момент учинення протиправних дій вік 33 \% злочинців не перевищував 20 років; 13 \% - старші 40 років; 54 \% мали вік від 20 до 40 років);

- деякі обставини скоєння злочину (вони залежать від багатьох факторів, зокрема на що саме була спрямована протиправна дія) [14, с. 13]. Виходячи з аналізу світової та вітчизняної практик, О. Мотлях пропонує розташувати їх у такій послідовності:

- корисливі - на долю яких припадає 66 \% комп' ютерних злочинів;

- політичні - 17 \% (шпигування, підрив фінансово-економічної діяльності та кредитної політики);

- цікавість, допитливість - 7 \%;

- хуліганські наміри - 5 \%;

- помста $-5 \%$.

Подані елементи криміналістичної характеристики, як зауважує автор, перебувають у взаємозв'язку, взаємодоповнюють один одного й виступають логічним продовженням попереднього структурного елементу.

Тоді як А. Білоусов, здійснюючи криміналістичний аналіз об'єктів комп'ютерних злочинів у межах учення про криміналістичну характеристику злочинів, обгрунтував доцільність розроблення криміналістичної характеристики комп'ютерних злочинів як міжвидової, що відображує закономірності злочинів, учинених із використанням комп'ютерної техніки та інформаційних технологій [11]. Водночас дослідникакцентує увагу на потребі використання спеціальних знань у розслідуванні комп'ютерних злочинів, а також проведенні комплексних досліджень комп' ютерних об' єктів. Науковець доповнив перелік основних завдань, що висуваються перед спеціалістом у разі його участі в проведені слідчих дій у справах цієї категорії. Розмірковуючи далі, учений стверджує, що у випадку розслідування комп'ютерних злочинів доцільно вести мову про міжвидову криміналістичну характеристику, що відображує закономірності злочинів, які вчиняються з використанням комп' ютерної техніки та інформаційних технологій. Основними елементами цієї криміналістичної характеристики, що, власне, i характеризують особливості злочинів, учинених із використанням комп'ютерної тех- 
ніки, є комп'ютерні об'єкти та специфічна віртуальна слідова картина, що відбивається на апаратних, програмних чи інформащійних елементах комп' ютерних об'єктів. У разі вчинення злочинів із використанням інформаційних технологій їх сліди мають істотні особливості, пов'язані з тим, що вчинення злочину здебілышого має на меті вплинути на комп' ютерну інформацію. Учинення таких злочинів пов' язане з використанням великого різноманіття носіїв комп'ютерної інформації, що мають різну природу - пам'ять комп'ютера, лінії електрозв'язку, роздруківки матеріалів із принтера тощо, для роботи з якими потрібні різноманітні технічні засоби, а в багатьох випадках - ще й навички та спеціальні знання [11, с. 5].

Слушною вважаємо думку О. Моїсеєва, що під час розслідування шахрайств, учинених із використанням ЕОТ, зокрема й кіберзлочинів дослідження комп' ютерної техніки доцільно проводити в умовах криміналістичної лабораторії, де цю роботу виконують фахівці з необхідною професійною підготовкою, адже докази, які були вилучені з місця події та пов'язані з комп'ютерними злочинами, можуть бути легко змінені як у результаті помилок при їх вилученні, так і в процесі самого дослідження [15]. Саме тому, на думку О. Миколенка, до якої схилясмось і ми, попри деюре, відсутність законодавчої вимоги про обов'язкове призначення експертизи в цих провадженнях, де-факто, без призначення та проведення експертизи не можна говорити про ефективне розслідування таких справ [16].

Ще одним науковим напрямом досліджень проблем розслідування шахрайств, учинених із використанням ЕОТ, є визначення організаційних заходів, що являють собою ефективний спосіб захисту інформації та реальний фундамент, на якому будується вся система захисту.

Отже, апелюючи до наукової позищії С. Чернявського [17], уважаємо, що аналіз стану наукового забезпечення розслідування шахрайств, учинених із використанням електронно-обчислювальної техніки, дає змогу говорити про дві тенденщії, що визначають перспективи формування окремих методик, - деталізацію та інтеграцію. Потребу деталізащії методик визначають особливості слідчих ситуащій, що складаються, та інші обставини злочинної діяльності [18; 19]. Поряд із процесом деталізації розгорнувся процес інтеграції методик, коли почали створювати міжвидові групи злочинів, що відбивають особливості розслідування споріднених видів (комплексів) злочинів.

Водночас сучасні науковці (А. Білоусов, О. Мусієнко, С. Самойлов, В. Тіщенко, С. Чернявський та ін.) наголошують на потребі розробки комплексної методики розслідування шахрайств, учинених із використанням ЕОТ, оскільки практика розслідування свідчить, що в кримінальному середовищі складаються складні схеми злочинної діяльності. Це положення створює потребу розробки загальних методикокриміналістичних рекомендацій із розслідування цих злочинів на основі їх узагальнених криміналістичних характеристик [20; 21, с. 64].

Висновки. Отже, сучасний стан боротьби з шахрайствами, учиненими з використанням ЕОТ, визначив для криміналістики низку невирішених завдань. Найбільш суттєві з них - у галузі криміналістичної методики, оскільки саме тут прослідковується основне відставання рівня науково-методичних рекомендацій від потреб практики. Ідеться не лише про відсутність методик розслідування «нових» злочинів, а й про застарілість підходів до розслідування тих діянь (зокрема, шахрайства), що, 
зберігаючи стару кримінально-правову форму, значно змінилися змістовно. Нині розробка окремих методик у криміналістищі ведеться за шаблоном, у якому практичний аспект незрідка загалом відсутній, тоді як їх основою мають бути саме методи, адаптовані до рівня сприйняття конкретним користувачем. Наразі є об'єктивна потреба в узагальненні та впорядкуванні наявних методичних рекомендацій розслідування виявів шахрайств, учинених із використанням ЕОТ, для формування комплексної криміналістичної методики. Об'єднані в єдиній класифікаційній групі ідеї та теоретичні положення стають цілісною теоретичною конщепщією, в основі якої - характеристика різних видів злочинів, урахування якої дає змогу об'єднати окремі рекомендащії в єдину методику. До допоміжних компонентів цієї конщепщії належать положення криміналістичної класифікації злочинів, криміналістична характеристика злочинів, теорія криміналістичного прогнозування та ін.

\section{Використані джерела:}

1. Про національну безпеку України: Закон України від 21 червня 2018 року № 2469VIII. URL:https://zakon.rada.gov.ua/laws/show/2469-19\#n355.

2. Тищенко Є. Ф. Розслідування комп' ютерних злочинів: наук.-метод. посіб. Київ: Вид-во НА СБУ, 2010.124 с.

3. Susan H. Nycum. The Criminal Law Aspects of Computer Abuse: Applicability ofthe State Penal Laws to Computer Abuse (Menlo Park, California, Stanford Research Institute, 1976). Ulrich Sieber, Computerkriminalität und Strafrecht (Cologne, Karl Heymanns Verlag, 1977). URL:http:// www.worldcat.org/title/criminal- law- aspects- of-computer- abuse- applicability- of- the-state- pe nal-laws- to- computerabuse/oclc/654145221/editions?referer=di\&editionsView=true.

4. Конвенція про кіберзлочинність від 23 листопада 2001 року (ратифікована Україною iз застереженнями і заявами від 07 вересня 2005 року). URL:http://zakon.rada.gov.ua/cgibin/laws/main.cgi?nreg=994_575.

5. Козак Н. Криміналістичні аспекти поняття «комп' ютерні злочини». Підприємницmbo, господарство і право. 2013. № 2. C. 23-28.

6. Кузнецов В. Комп'ютерна крадіжка: що розуміти під предметом злочину. Право України. 1999. № 10. С. 74-76.

7. Баулін Ю. В., Борисов В. І., Тютюгін В. І. та ін. Кримінальне право України: Особлива частина: підручник; за ред. В. В. Сташиса, В. Я. Тація; 4-те вид, переробл. і допов. Харків: Право, 2010. 608 с.

8. Хавронюк М. І. Довідник з Особливої частини Кримінального кодексу України. Київ: Істина, 2004. 504 с.

9. Біленчук П. Д., Гель А. П., Семаков Г. С. Криміналістична тактика і методика розслідування окремих видів злочинів. Київ, 2007. 512 с.

10. Стрільців О. М., Крижна В. В., Максименко О. В. та ін. Особливості розслідування кримінальних правопорушень, пов'язаних із розповсюдженням у мережі Інтернет забороненого контенту: метод. рек.; за заг. ред. Ю. Ю. Орлова. Київ: Нац. акад. внутр. справ, 2014. $80 \mathrm{c}$.

11. Білоусов А. С. Криміналістичний аналіз об'єктів комп'ютерних злочинів: автореф. дис. ... канд. юрид. наук: 12.00.09. Київ, 2008. 20 с.

12. Шапочка С. В. До питання запобігання окремим видам шахрайства, яке вчиняється з використанням можливостей мережі Інтернет. Боротьба з організованою злочинністю і корупцією (теорія і практика). 2014. № 1. С. 145-149.

13. Голубєв В. О. Розслідування комп'ютерних злочинів: монографія. Запоріжжя: Гуманітарний університет «ЗІДМУ», 2003. 296 с. 
14. Мотлях О. І. Питання методики розслідування злочинів у сфері інформаційних комп'ютерних технологій : автореф. дис. ... канд. юрид. наук : 12.00.09. Київ, 2005. 20 с.

15. Моїсеєв О. М. Залучення спеціаліста до розслідування комп' ютерних злочинів. Правові основи захисту комп'ютерної інформаиії від протиправних посягань: матеріали міжвузівської наук.-практ. конф. (м. Донецьк, 22 грудня 2000 р.). Донецький інститут внутрішніх справ, 2001. С. 81-85.

16. Миколенко О. М. Деякі особливості розслідування злочинів у сфері використання електронно-обчислювальних машин (комп' ютерів), систем та комп' ютерних мереж і мереж електрозв'язку. Кібербезпека 6 Україні: правові та організаційні питання: матеріали Всеукр. наук.-практ. конф. (м. Одеса, 21 жовтня 2016 р.). Одеса: ОДУВС, 2016. с. 155-157.

17. Чернявський С. С. Фінансове шахрайство: методологічні засади розслідування: монографія. Київ, 2010.624 с

18. Анапольська А. І., Коваленко В. В., Корякін Р. В. та ін. Особливості розслідування шахрайств, учинених у сфері функціонування електронних розрахунків: метод. рек. Луганськ, 2010.56 с.

19. Користін О. С., Бутузов В. М., Василевич В. В. та ін. Протидія кіберзлочинності в Україні: правові та організаційні засади: навч. посіб. Київ: Видавничий дім «Скіф», 2012. 728 с.

20. Самойлов С. В. Розслідування шахрайств, учинених із використанням мережі «нттернет»: дис. канд. юрид. наук: 12.00.09. Донецьк, 2014. 100 с.

21. Тіщенко В. В. Теоретичні і практичні основи методики розслідування злочинів: монографія. Одеса: Фенікс, 2007. 260 с.

\section{References:}

1. Pro natsionalnu bezpeku Ukrainy: Zakon Ukrainy vid 21 chervnia 2018 r. № 2469-VIII. URL:https:/ / zakon.rada.gov.ua/laws/show/2469-19\#n355. [in Ukrainian].

2. Tyshchenko, Ye. F. (2010) Rozsliduvannia komp'iuternykh zlochyniv: nauk.-metod. posib. Kyiv: Vyd-vo NA SBU. [in Ukrainian].

3. Susan, N. Nycum. (1976) The Criminal Law Aspects of Computer Abuse: Applicability ofthe State Penal Laws to Computer Abuse (Menlo Park, California, Stanford Research Institute, 1976). Ulrich Sieber, Computerkriminalität und Strafrecht (Cologne, Karl Heymanns Verlag, 1977). URL:http:/ / www.worldcat.org/title/criminal-law-aspects-of-computer-abuseapplicability-of-the-state-penal-laws-to-computerabuse/oclc/654145221/editions? referer=di\&editionsView=true. [in English].

4. Konventsiia pro kiberzlochynnist vid 23 lystopada 2001 r. (ratyfikovana Ukrainoiu iz zasterezhenniamy i zaiavamy vid 7 veresnia 2005 r). (2005) N. p. URL:http://zakon.rada.gov.ua/cgibin/laws/main.cgi?nreg=994_575. [in Ukrainian].

5. Kozak, N. (2013) Kryminalistychni aspekty poniattia «komp'iuterni zlochyny». Pidpryiemnytstoo, hospodarstoo i pravo - Entrepreneurship, economy and law, 2, 23-28. [in Ukrainian].

6. Kuznetsov, V. (1999) Komp'iuterna kradizhka: shcho rozumity pid predmetom zlochynu. Pravo Ukrainy - Law of Ukraine, 10, 74-76. [in Ukrainian].

7. Baulin, Yu. V., Borysov, V. I., Tiutiuhin, V. I. et al. Kryminalne pravo Ukrainy: Osoblyva chastyna: pidruchnyk. V. V. Stashys, \& V. Ya. Tatsii (Eds.); Kharkiv: Pravo. [in Ukrainian].

8. Khavroniuk, M. I. (2004) Dovidnyk z Osoblyvoi chastyny Kryminalnoho kodeksu Ukrainy. Kyiv: Istyna. [in Ukrainian].

9. Bilenchuk, P. D., Hel, A. P., Semakov, H. S. (2007) Kryminalistychna taktyka i metodyka rozsliduvannia okremykh vydiv zlochyniv. Kyiv. [in Ukrainian].

10. Striltsiv, O. M., Kryzhna, V. V., Maksymenko, O. V. et al. (2014) Osoblyvosti rozsliduvannia kryminalnykh pravoporushen, pov'iazanykh iz rozpovsiudzhenniam u merezhi 
Internet zaboronenoho kontentu: metod. rek. Yu. Yu. Orlov (Ed.). Kyiv: Nats. akad. vnutr. sprav. [in Ukrainian].

11. Bilousov, A. S. (2008) Kryminalistychnyi analiz ob'iektiv komp'iuternykh zlochyniv. Extended abstract of candidate's thesis. Kyiv. [in Ukrainian].

12. Shapochka, S. V. (2014) Do pytannia zapobihannia okremym vydam shakhraistva, yake vchyniaietsia $\mathrm{z}$ vykorystanniam mozhlyvostei merezhi Internet. Borotba $z$ orhanizovanoiu zlochynnistiu i koruptsiieiu (teoriia i praktyka) - Fight against organized crime and corruption (theory and practice), 1, 145-149. [in Ukrainian].

13. Holubiev, V. O. (2003) Rozsliduvannia kompiuternykh zlochyniv: monohr. Zaporizhzhia: Humanitarnyi universytet «ZIDMU». [in Ukrainian].

14. Motliakh, O. I. (2005) Pytannia metodyky rozsliduvannia zlochyniv u sferi informatsiinykh komp'iuternykh tekhnolohii. Extended abstract of candidate's thesis. Kyiv. [in Ukrainian].

15. Moiseiev, O. M. (2001) Zaluchennia spetsialista do rozsliduvannia komp'iuternykh zlochyniv. Pravovi osnovy zakhystu komp'iuternoi informatsii vid protypravnykh posiahan: materialy mizhouzivskoi nauk.-prakt. konf. (m. Donetsk, 22 hrudnia 2000 r.).- Pravovi osnovy zakhystu komp'iuternoi informatsii vid protypravnykh posiahan: materialy mizhouzivskoi nauk.-prakt. conf. (Donetsk, December 22, 2000). Donetskyi instytut vnutrishnikh sprav, 81-85. [in Ukrainian].

16. Mykolenko, O. M. (2016) Deiaki osoblyvosti rozsliduvannia zlochyniv u sferi vykorystannia elektronno-obchysliuvalnykh mashyn (komp'iuteriv), system ta komp'iuternykh merezh i merezh elektrozv'iazku. Kiberbezpeka $v$ Ukraini: pravovi ta orhanizatsiini pytannia: materialy Vseukr. nauk.-prakt. konf. (m. Odesa, 21 zhovtnia 2016 r.). - Cybersecurity in Ukraine: legal and organizational issues: materials All-Ukrainian. scientific-practical conf. (Odessa, October 21, 2016). Odesa: ODUVS, 155 157. [in Ukrainian].

17. Cherniavskyi, S. S. (2010) Finansove shakhraistvo: metodolohichni zasady rozsliduvannia: monohr. Kyiv. [in Ukrainian].

18. Anapolska, A. I., Kovalenko, V. V., Koriakin, R. V. et al. (2010) Osoblyvosti rozsliduvannia shakhraistv, uchynenykh u sferi funktsionuvannia elektronnykh rozrakhunkiv: metod. rek. Luhansk. [in Ukrainian].

19. Korystin, O. Ye., Butuzov, V. M., Vasylevych, V. V. et al. (2012) Protydiia kiberzlochynnosti v Ukraini: pravovi ta orhanizatsiini zasady: navch. posib. Kyiv: Vydavnychyi dim «Skif». [in Ukrainian].

20. Samoilov, S. V. (2014) Rozsliduvannia shakhraistv, uchynenykh iz vykorystanniam merezhi «Internet». Candidate's thesis. Donetsk. [in Ukrainian].

21. Tishchenko, V. V. (2007) Teoretychni i praktychni osnovy metodyky rozsliduvannia zlochyniv: monohr. Odesa, Feniks. [in Ukrainian].

Стаття надійшла до редколегіï 12.08.2020

Романенко Т. В., адъюнкт кафедры криминалистики и судебной медицины Национальной академии внутренних дел

(г. Киев, Украина)

\section{СОСТОЯНИЕ НАУЧНЫХ ИССЛЕДОВАНИЙ ПРОБЛЕМ РАССЛЕДОВАНИЯ МОШЕННИЧЕСТВ, СОВЕРШЕННЫХ С ИСПОЛЬЗОВАНИЕМ ЭЛЕКТРОННО-ВЫЧИСЛИТЕЛЬНОЙ ТЕХНИКИ}

В статье обозначено состояние научных исследований проблем расследования мошенничеств, совершенных с использованием электронно-вычислительной техники. Выяснено, что развитие современных информационных технологий, усовершенствования 
производства и расширения области применения новейшей кибернетической техники дали возможность зарождения специфического, сложного вида преступных деяний, где компьютерная оснастка и электронная информация является объектом противоправного посягательства. Установлено, что рядом с позитивными достижениями информатизация сопровождается побочным негативным явлением криминогенного характера, к которому относят преступления в сфере электронно-вычислительных машин (компьютеров), систем и компьютерных сетей или же «компьютерную преступность» (сокращенное название этого вида преступлений). Констатировано отсутствие единой мысли относительно того, какие именно элементы необходимо включать в криминалистическую характеристику преступлений в сфере использования электронно-вычислительной техники (компьютеров), систем и компьютерных сетей и сетей электросвязи.

Ключевые слова: электронная вычислительная техника, кибербезопасность, компьютерные технологии, расследования мошенничества, мошенничество.

\section{Romanenko T., Adjunct of the Department of Criminalistics and Forensic Medicine of the National Academy of Internal Affairs \\ (Kyiv, Ukraine)}

\section{THE CONDITION OF SCIENTIFIC RESEARCHES OF INVESTIGATION PROBLEMS OF THE FRAUD COMMITTED WITH THE USE OF ELECTRONICS AND COMPUTER TECHNOLOGIES}

In this article it has been analyzed the condition of scientific researches of investigation problems of the fraud committed with the use of electronics and computer technologies. It has been revealed that the development of modern information technologies, improvement of production and expansion of the sphere of application of the up-to-date cybernetic technology have given rise to inception of a specific and complex type of criminal acts, where computer equipment and electronic information are the objects of unlawful infringements. It has been established that alongside the positive achievements, information development is accompanied by a side-effect and negative phenomenon of criminal character, which include crimes in the field of electronics and computer technologies (computers), systems and computer networks, or "computer crime" (abbreviated name of this type of crimes). It has been defined the lack of unanimity regarding the issue about which elements should be included in the criminalistics features of crimes in the field of the use of electronics and computer technologies (computers), systems and computer networks and telecommunication networks.

Keywords: electronics and computer technologies, cyber security, computer technologies, investigation of fraud, fraud. 